\title{
Analysis and Diagnosis: Energy Consumption and Waste on a 660MW Supercritical Power Generating Unit
}

\author{
ZHAO Zhenning ${ }^{1, ~ a ~, ~ L I ~ Y u a n y u a n ~}{ }^{2, b}$,LI JingJing ${ }^{3, c}$ and Zhang Qingfeng ${ }^{4, d}$ \\ ${ }^{1,2,3,4}$ Full address of first author, including country \\ a'Zhaozn@sina.com
}

\begin{abstract}
Keywords: Energy; Power generating unit; Energy consumption analysis, Staged indexes.
Abstract. Analysis and Diagnosis work are important jobs to find out the energy over consumed steps in the power generating process, and how to avoid these energy over consumptions. A suit of analysis and diagnosis methodology including staged indexes and methods are presented and a diagnosis application example on a 660MW supercritical power generating unit is conducted in this document. Impact factors, their performance effecting ways and corresponding counteracting measures are fully analyzed, can be a useful reference as solving such total performance promotion problem.
\end{abstract}

\section{Introduction}

Analysis and diagnosis are very important jobs for a power generating unit to find out where energy is over consumpted, how these energies are wasted and how to avoid these energy wastes. It is the fundamental of operation optimization, control optimization and even retrofit optimization. Fragmentary applications of such principle are common in daily operation of power plants, and most of these applications are diagnosis on turbines [1-4]. Sun has conducted a diagnosis covered both boiler and turbine on a modern 1000MW power generating unit[5], but only gives the diagnosis results. There are still few systematic studies in this field, both on methodology and the diagnosis work itself, in China now. Such an full application for two 660MW supercritical power generating units by detailed comprehensive comb of energy consumption comparing the design and the real performance, undergoing the transformation roadmap from coal before boiler to the emission and power generated, is conducted in Hebei province North China, over energy consumption practices are found out and according measures \& proposals to lower these energy wastes are presented. By these experiences, methodology of energy consumption and waste analysis and diagnosis are also concluded in this document, works as references for solving such problems.

\section{General Information of the Research Object Units}

The research objects include two supercritical units both composed by a SG-2080/25.4-M969 boiler made based on imported ALSTOM technology by Shanghai Boiler Works and a CLN660-24.2/566/566 steam turbine made by Harbin Turbine Company Ltd.. The design coal of the boiler is Jinbei bitumite of Shanxi province North China and the actual burned coal is Shenghua bitumite coal. Both units of NO.3 and NO.4 had been put into commercial operation at 2009, should have the highest power generation efficiency level as their supercritical parameters and advanced technologies, but only a middle level efficiency had been reached, sometimes even lower than their 600MW subcritical neighbour units. So it is very important to conduct a comprehensive diagnosis and analysis of energy consumption and waste to find out where energy is wasted and how to avoid these wastes.

\section{Methodology of diagnosis and analysis}

Point of view. For performance, most main equipments of boiler-turbine-generator power generating process mode have their own performance test code can guide relative work. But all of these performance test code, the center object is the equipment itself, all of inappropriate condition are compared by the equipment's need or design condition, all of these inappropriation are corrected by 
parameters relative to the equipments itself, but not the whole power generating process, makes some reconsideration or some misconsideration. Such as: the boiler's main output steam temperature, commonly be considered has no relationship to the boiler efficiency, but will be used to correction calculation of turbine efficiency. But for a whole formed power generation process, these correction performance will not be achieved forever if the procedure keeps not being changed itself. So obviously the efficiency of whole power generating procedure should be the only performance consideration based on the guarantee of security and pollutant emissions. For those big equipment performance indexes such as boiler efficiency, can be viewed as the causes, and for the performance determination, only corrections of the outer condition change should be viewed essential.

The decomposition of performance indexes. In China, the standard coal consumption rate (SCCR) at unit electric power supplied basis is often utilized to measure the efficiency, so the performance indexes of a units used are shown as table 1. In order to find out these impact factors and their impact weights, these performance indexes are divided into 3 levels corresponding to the plant-level, the unit(boiler-turbine-generator) level and each sub impact factor level such as a relative parameter, a equipment or a device running mode. By undergoing and tracing follow this tree-type decomposition, the corresponding retrofit or adjusting measures can also be concluded when the energy overconsumption steps are located.

Table 1 Indexes to evaluate the performance of a power gernerating unit

\begin{tabular}{|c|c|c|}
\hline Indexes Level I & Indexes Level II & Impact factors \\
\hline \multirow{3}{*}{$\begin{array}{l}\text { SCCR at unit electric } \\
\text { power supplied } \\
\text { basis }(\mathrm{b}) / \mathrm{g} \cdot \mathrm{kWh}^{-1}\end{array}$} & $\begin{array}{r}\text { Boiler heat } \\
\text { efficiency }\left(\eta_{\mathrm{b}}\right) / \%\end{array}$ & $\begin{array}{l}\text { Exhausting flue gas temperature, Oxgen content of flue } \\
\text { gas,uncombusted carbon in residues, air heater leakage,coal } \\
\text { fitness,boiler control and operation mode,etc. }\end{array}$ \\
\hline & $\begin{array}{l}\text { Turbine-gernerator } \\
\text { unit efficiency(reciprocal } \\
\text { value of the Heat } \\
\text { consumption rate of } \\
\text { turbine-gernerator unit, } \\
\left.\eta_{\mathrm{T}}\right) / \%\end{array}$ & $\begin{array}{l}\text { Efficiency of High pressure cylinder(HP), Efficiency of } \\
\text { intermediate pressure cylinder(IP) and low pressure } \\
\text { cylinder(LP),main steam temperature, reheat steam } \\
\text { temperature, main steam pressure,reheat steam pressure, } \\
\text { desuperheating water flux, reheating desuperheat water flux, } \\
\text { condenser vacuum,vaccum leakage,condenser terminal } \\
\text { temperature difference(TTD),condensed water subcooling } \\
\text { degree, feed water temperature, TTDs of each heater,service } \\
\text { rate of high pressure heater,etc. }\end{array}$ \\
\hline & $\begin{array}{l}\text { Auxiliary power } \\
\text { consumption } \\
\text { rate(APCR, \%) }\end{array}$ & $\begin{array}{l}\text { APCR of mills, Primary Air Fans(PAF), Forced draft } \\
\text { Fans(FDF), Induced Draft Fan(IDF), condenser circulating } \\
\text { water pump, dondeser pump,motor-driven feedwater } \\
\text { pump,electrostatic precipitator, coal conveyer, flue gas } \\
\text { desulfurization, non-production and heat supply devices }\end{array}$ \\
\hline
\end{tabular}

The relationship of index-level I and index-level II in table 1 is:

$$
\left\{\begin{array}{l}
b=\frac{122.8}{0.99 \frac{\eta_{B}}{100} \frac{\eta_{T}}{100}\left(1-\frac{A P C R}{100}\right)} \\
\Delta b=-100 b\left(\frac{\Delta \eta_{B}}{\eta_{B}}+\frac{\Delta \eta_{T}}{\eta_{T}}+\frac{\Delta A P C R}{A P C R}\right)
\end{array}\right.
$$

The deserved (desired) and actual performance determination: Accurately determination the deserved and actual performance is a very important step. Besides the indexes from the factors in table 1 , the unit working condition must be considerd, including the unit output coefficient and the magnatitude of heat supply, because these condition base parameters will have big influences to $\eta \mathrm{b}, \eta \mathrm{T}$ and APCR. The actual performances are determined by formal acceptance test as commonly done. The deserved or desired performance is mainly determinated by designed boiler and designed turbine-generator efficiency given by their manufacturer. Because the designed APCR value is commonly estimated by the power consulting group in China and has a great devaition value, both 
deserved and actual performance adopt the test measured APCR values, corrected to the unit working output level.

Correct method: both of design and test-measured boiler efficiencies and turbine-generator efficiencies at different output capacity, $100 \%$ turbine heat rate acceptance power(THA),75\% THA and 50\% THA are corrected to their design conditions according to different outer factors such as the ambient temperature. APRCs of the three output coefficient are statisted. Then the design performance and actual performance and effectiveness of some items can be determined by formula(1).

The reference object: Except to the comparson between the actual and deserved performance itself, a benchmarking against Wushashan Power plant, which works as the best practice reference, is also implemented to find out the performance difference or energy saving potential.

\section{Analysis and diagnosis}

Current energy consumption status: Current energy consumption status of each steps in the power generating process are shown in table 2 . These data reveal that the general performance get by statistics and by test are very close, means that the precision of statistics data can meet analysis requirement. Both of statistic performance data and test-measured data can be utilized together for performance evuation and causes diagnosis and analysis.

Table 2 current energy consumption status under different working conditions

\begin{tabular}{|c|c|c|c|c|c|c|}
\hline & \multirow{2}{*}{ items } & \multicolumn{2}{|c|}{$100 \%$ ТHА } & \multirow{2}{*}{$\begin{array}{c}75 \% \text { THA } \\
\text { by test }\end{array}$} & \multirow{2}{*}{$\begin{array}{c}50 \% \text { THA } \\
\text { by test }\end{array}$} & \multirow{2}{*}{$\begin{array}{c}\text { Statistic } \\
\text { performance }^{(*)}\end{array}$} \\
\hline & & design & by test & & & \\
\hline \multirow{4}{*}{ Unit No.3 } & Boiler efficiency/\% & 93.64 & 94.18 & 93.62 & 93.50 & 95.12 \\
\hline & $\begin{array}{l}\text { Turbine-generator } \\
\text { efficiency } / \%\end{array}$ & 47.95 & 45.11 & 44.69 & 43.28 & 43.63 \\
\hline & $\mathrm{APRC} \%$ & 4.76 & 4.249 & 4.924 & 6.154 & 4.76 \\
\hline & $\begin{array}{l}\text { SCCR at unit electric power } \\
\text { supplied basis } / \mathrm{g} \cdot(\mathrm{kW} \cdot \mathrm{h})^{-1}\end{array}$ & 299.7 & 305.4 & 312.3 & 327.1 & 308.12 \\
\hline \multirow{4}{*}{ Unit No.4 } & Boiler efficiency $/ \%$ & 93.64 & 93.97 & 93.87 & 94.08 & 94.13 \\
\hline & $\begin{array}{c}\text { Turbine-generator } \\
\text { efficiency } / \%\end{array}$ & 47.95 & 45.64 & 45.06 & 44.00 & 43.64 \\
\hline & $\mathrm{APRC} \%$ & 4.76 & 4.33 & 4.963 & 6.52 & 4.77 \\
\hline & $\begin{array}{l}\text { SCCR at unit electric power } \\
\text { supplied basis } / \mathrm{g} \cdot(\mathrm{kW} \cdot \mathrm{h})^{-1}\end{array}$ & 299.7 & 302.8 & 309.04 & 321.1 & 312.92 \\
\hline
\end{tabular}

Note: for unit NO.3 the output coefficient is $81 \%$, and for unit NO.4 is $71 \%$.

Obviously the main problems of these two supercritical units exist in the turbine-generator step in most cases. For the boiler step, all of the boiler efficiencies are higher than design values superficially, but there are still some problems can been found from the test-measured detailed items, because the actually burned coal has changed to a more easily inflammable SHENHUA coal and should have a more higher boiler efficiency. For the APRCs, by referring to those benchmarking units, also have some optimization space.

\section{Analysis Results:}

1)Equipment related problems, their causes and effectiveness. Equipment related problems include mainly three types: larger or smaller equipment model selection, unqualified equipment performance, and other failure mode. Work of retrofit, equipment improvement or system redesign must been applied to overcome these failures, as list follows: 
(1) The most effective factor of turbine side is the unqualified performance of the three cylinder, makes unit NO.3 heat comsumption rate $253.3 \mathrm{~kJ} /(\mathrm{kW} \cdot \mathrm{h})$ higher and $8.84 \mathrm{~g} /(\mathrm{kW} \cdot \mathrm{h}) \mathrm{SCCR}$ at power supply basis higher than design condition, makes unit NO.4 heat comsumption rate $245.8 \mathrm{~kJ} /(\mathrm{kW} \cdot \mathrm{h})$ higher and $8.57 \mathrm{~g} /(\mathrm{kW} \cdot \mathrm{h}) \mathrm{SCCR}$ at power supply basis higher than design condition.

(2) The most effective factor of boiler side is too larger capacity selection of the induced draft fan(IDF) and the booster fan(BF) for desulfurization system, makes 0.4 0.5\% APRC and $0.95 \sim 1.2 \mathrm{~g} /(\mathrm{kW} \cdot \mathrm{h}) \mathrm{SCCR}$ at power supply basis higher than desired performance for both unit NO.3 and unit NO.4. In detail, the speed is too high for the IDF and the total pressure increase is too high for the BF.

(3) Some imperfect designs, such as: all of the ash blowers using one steam source from the outlet head of secord superheater. the steam air heater coil using relatively high pressure bleeding steam No.4, have total about $0.6 \mathrm{~g} /(\mathrm{kW} \cdot \mathrm{h}) \mathrm{SCCR}$ higher at power supply basis.

(4) Some small problems such as spattered sparks in the residues truck make an about $10^{\circ} \mathrm{C}$ lower mill outlet temperature leading the whole boiler run at an about $0.2 \%$ lower level efficiency mode by utilizing too much cold primary air in order to eliminate the residues combustion, although they looks like having little relationship with the boiler's efficiency.

Operation mode related problems, their causes and effectiveness. Although the better combustion rate of the more imflamble SHENHUA coal makes a over design efficiency, there still some problems related to operation mode. These problems are caused by some imprefect unit control philosophy and unit control methods. These probem should be settled by changing relative control mode, mainly as :

(1)The main superheat steam temperature can really reach the design $540^{\circ} \mathrm{C}$, but under normal running conditions, it is $3 \sim 5^{\circ} \mathrm{C}$ lower. Although it has a only as little as $0.1 \sim 0.2 \mathrm{~g} /(\mathrm{kW} \cdot \mathrm{h}) \mathrm{SCCR}$ effectiveness, but it is purely caused by ill operation custom, so it can been fully avoided indeed.

(2) The reheat steam temperature has an about $10^{\circ} \mathrm{C}$ lower than the design value $540^{\circ} \mathrm{C}$, makes the SCCR have a $0.6 \sim 1.2 \mathrm{~g} /(\mathrm{kW} \cdot \mathrm{h})$ effectiveness.

(3) About $10 \sim 15^{\circ} \mathrm{C}$ boiler exhausting flue gas temperature higher than the desired value makes the SCCR have a $1.6 \sim 2.5 \mathrm{~g} /(\mathrm{kW} \cdot \mathrm{h})$ effectiveness, is the biggest problem of boiler side.

\section{Unit control mode related problems, their causes and effectiveness.}

(1)For both units, the whole annual average output coefficeiencies are only $70 \% \sim 80 \%$, make the SCCR about $1.8 \mathrm{~g} /(\mathrm{kW} \cdot \mathrm{h}) \sim 4.1 \mathrm{~g} /(\mathrm{kW} \cdot \mathrm{h})$ higher than the desired level. Because of the power generating full market characteristic the output coefficeicy can not adjustment.

(2)In order to speed up the output capacity response of the electrical grid, the unit has a very high pressure sliding steam pressure control curve, about 6Mpa higher pressure than normal control value for such unit or the design sliding steam pressure control curve, has a very important role in current lower reheat temperature and lower turbine cylinder efficiency, lead to a $2.4 \sim 4 \mathrm{~g} /(\mathrm{kW} \cdot \mathrm{h}) \mathrm{SCCR}$ decline of the whole unit perfromance.

\section{Measures and Solutions}

According to these problems diagnosed before, relatively measures are reseached and their importance of each job are list as follows:

(1) The posibility study of shutting down the booster fan, appling the induced draft fan as the only power source to overcome the flue gas exhaustion and the desulfurization system resistance, should be conducted. If it can meet the pressure requirement, can make the SCCR lower about 0.95 1.2 $\mathrm{g} /(\mathrm{kW} \cdot \mathrm{h})$.

(2) Much lower main steam pressure should be applied under each varied output capacities than current too high sliding curve. It will not only has an very good advantage for raise the reheat steam temperature by lower the reheat steam pressure, but also has a very importante promotion of turbine by reducing the throttling losses and high reheat steam pressure. Besides it can also lower the feed water 
pump power need if the pressure of main steam are lowerd. At 75\% THA condition, total about 1.1 $\mathrm{g} /(\mathrm{kW} \cdot \mathrm{h}) \mathrm{SCCR}$ can be saved and at least $0.8 \mathrm{~g} /(\mathrm{kW} \cdot \mathrm{h}) \mathrm{SCCR}$ at $50 \% \mathrm{THA}$ condition.

(3)Current steam airheater coil utilizes bleeding steam NO.4 as the heating source, if it is changed to heat by later bleeding steam No. 5, can save SCCR $0.9 \mathrm{~g} /(\mathrm{kW} \cdot \mathrm{h})$ but has no effects to both boiler and turbine. If the blower steam source change from secord superheater outlet to the middle pressure reheater outlet, can increase the safety of the throttle valve on blowing pipe line and has about 0.28 $\mathrm{g} /(\mathrm{kW} \cdot \mathrm{h}) \mathrm{SCCR}$ drop.

(4) By optimizing the operating mode of the circulatint water pump according to different ambient temperature condition, circulatiing pump power consumtion and the turbine efficiency, can make a SCCR about $0.9 \mathrm{~g} /(\mathrm{kW} \cdot \mathrm{h})$ dropping.

(5) An deep the boiler combustion and running mode optimization adjustment work should be conducted to strengthen the heat exchange, lower the exhausting flue gas temperatue and speed up the load response from the electrical grid. Meanwhile, the lower sliding pressure curve control should be also based on the optimization of the unit, so the boiler combustion and running mode optimization adjustment work is the core job for the whole measures.

\section{Conclusion}

By strictly performance tests, comparing analysis of designed parameters and characteristics releatively corrected calculation according to local ambient condition, statistics data of performance, reseanable deserved(desired) unit performance is determined for two supercritical 600MW power generating units. The basing on the comparson between the desired performance and the design performance, by the comparson between the objective units and the benchmarking unit, the performance degraded points of the units, their causes and effecting ways are found out, then responding measures are researched to avoid these degraded points. By this practice, a suit of methodology against energy consumption and waste analysis and diagnosis are also concluded, can be a useful tool for promoting the integral performance of the whole power generating unit.

\section{References}

[1]ZHU Yewei , ZHAO Qingsen , SUN Quanrong . Thermal economy analysis on CZKl50/145-13.2/0.294/535/535 turbine[J] . Thermal Power Generation , 2012(12):5-7

[2]ZHANG Buting, WANG Chunyu , LI Ling, et al . Energy-saving transformation of rotary air preheater for boiler on a $600 \mathrm{MW}$ unit $[\mathrm{J}]$. Thermal Power Generation , 2012(10):64-65

[3]LI Peifeng , YANG Yongping , GE Zhihua , et al . Analysis and calculation on energy consumption of $300 \mathrm{MW}$ CHP heating systems[J] . Proceedings of the CSEE , 2012 , 32(23):15-20 [4]WANG Yang , JIANG You , LUO Yang, etal . Impact of heater type and arrangement on thermal efficiency of power plant[J] . Shanxi Electric Power , 2012 , 40(6):59-62 .

[5]SUN Zhichun , Energy consumption of 1000 MW units: diagnosis and analysis[J]. Thermal Power Generation, 2013, 42(5):19-21,37 